\title{
Bupropion Inhibits Serotonin Type 3AB Heteromeric Channels at Clinically Relevant Concentrations
}

\author{
(i) Antonia G. Stuebler and 미 Michaela Jansen \\ Department of Cell Physiology and Molecular Biophysics and Center for Membrane Protein Research, School of Medicine, Texas \\ Tech University Health Sciences Center, Lubbock, Texas
}

Received September 25, 2019; accepted December 13, 2019

\section{ABSTRACT}

Bupropion, a Food and Drug Administration-approved antidepressant and smoking cessation aid, blocks dopamine and norepinephrine reuptake transporters and noncompetitively inhibits nicotinic acetylcholine and serotonin (5- HT) type 3A receptors (5- $\left.\mathrm{HT}_{3 \mathrm{~A}} \mathrm{Rs}\right)$. 5- $\mathrm{HT}_{3}$ receptors are pentameric ligandgated ion channels that regulate synaptic activity in the central and peripheral nervous system, presynaptically and postsynaptically. In the present study, we examined and compared the effect of bupropion and its active metabolite hydroxybupropion on mouse homomeric 5- $\mathrm{HT}_{3 \mathrm{~A}}$ and heteromeric $5-\mathrm{HT}_{3 \mathrm{AB}}$ receptors expressed in Xenopus laevis oocytes using two-electrode voltage clamp experiments. Coapplication of bupropion or hydroxybupropion with 5-HT dose dependently inhibited 5HT-induced currents in heteromeric 5-HT type 3AB receptors $\left(5-\mathrm{HT}_{3 A B} \mathrm{Rs}\right) \quad\left(\mathrm{IC}_{50}=840\right.$ and $526 \mu \mathrm{M}$, respectively). The corresponding $\mathrm{IC}_{50} \mathrm{~S}$ for bupropion and hydroxybupropion for homomeric 5- $\mathrm{HT}_{3 \mathrm{~A}} \mathrm{Rs}$ were 10- and 5-fold lower, respectively (87 and $113 \mu \mathrm{M}$ ). The inhibition of $5-\mathrm{HT}_{3 A} \mathrm{Rs}$ and $5-\mathrm{HT}_{3 A B} \mathrm{Rs}$ was non-use dependent and voltage independent, suggesting bupropion is not an open channel blocker. The inhibition by bupropion was reversible and time-dependent. Of note, preincubation with a low concentration of bupropion that mimics therapeutic drug conditions inhibits 5-HT-induced currents in 5$\mathrm{HT}_{3 \mathrm{~A}}$ and 5- $\mathrm{HT}_{3 \mathrm{AB}}$ receptors considerably. In summary, we demonstrate that bupropion inhibits heteromeric 5- $\mathrm{HT}_{3 A B} R$ s as well as homomeric $5-\mathrm{HT}_{3 \mathrm{~A}} \mathrm{Rs}$. This inhibition occurs at clinically relevant concentrations and may contribute to bupropion's clinical effects.

\section{SIGNIFICANCE STATEMENT}

Clinical studies indicate that antagonizing serotonin (5-HT) type $3 A B\left(5-\mathrm{HT}_{3 \mathrm{AB}}\right)$ receptors in brain areas involved in mood regulation is successful in treating mood and anxiety disorders. Previously, bupropion was shown to be an antagonist at homopentameric $5-\mathrm{HT}$ type $3 \mathrm{~A}$ receptors. The present work provides novel insights into the pharmacological effects that bupropion exerts on heteromeric $5-\mathrm{HT}_{3 \mathrm{AB}}$ receptors, in particular when constantly present at low, clinically attainable concentrations. The results advance the knowledge on the clinical effects of bupropion as an antidepressant.

\section{Introduction}

The 5-hydroxytryptamine-3, or serotonin (5-HT) type 3, receptor is an ionotropic receptor and a member of the Cysloop family of pentameric ligand-gated ion channels, and thereby, differs from G-protein-coupled serotonin receptors (Thompson and Lummis, 2007). The 5-HT type 3 receptor (5$\mathrm{HT}_{3} \mathrm{R}$ ) is similar in structure and function to other members of the pentameric ligand-gated ion channel family, including cation-selective nicotinic acetylcholine $(\mathrm{nACh})$ receptors (nAChRs) and anion-selective $\mathrm{GABA}_{\mathrm{A}}$ and glycine receptors. Malfunction in these receptors has been linked to several neurologic disorders (Lemoine et al., 2012). Together, they are responsible for fast neurotransmission in the central and

Research reported in this publication was supported in part by the National Institute of Neurologic Disorders and Stroke of the National Institutes of Health [R01 NS077114 (to M.J.)]. The content is solely the responsibility of the authors and does not necessarily represent the official views of the National Institutes of Health.

https://doi.org/10.1124/mol.119.118349. peripheral nervous system (Thompson and Lummis, 2013) and are involved in virtually all brain functions (Hassaine et al., 2014)

To date, five different $5-\mathrm{HT}_{3}$ subunits have been identified $\left(5-\mathrm{HT}_{3 \mathrm{~A}}-5-\mathrm{HT}_{3 \mathrm{E}}\right)$. The first subunit to be cloned, $5-\mathrm{HT}_{3 \mathrm{~A}}$ (Maricq et al., 1991), is the only subunit among these that can form functional homo-oligomeric receptors on the cell membrane when expressed in Xenopus oocytes or cell lines (Hussy et al., 1994). Introduction of the $5-\mathrm{HT}_{3 \mathrm{~B}}$ subunit yields functional heteromers with altered properties compared with the homo-oligomer and with heteromer function more closely resembling the functional responses observed in native tissues (Hussy et al., 1994; Davies et al., 1999). When compared with $5-\mathrm{HT}_{3 \mathrm{~A}}$, the 5 - $\mathrm{HT}$ type $3 \mathrm{AB}$ receptor $\left(5-\mathrm{HT}_{3 \mathrm{AB}} \mathrm{R}\right)$ differs in agonist concentration-response curves, shows increased singlechannel conductance and desensitization, and an altered current-voltage relationship (Davies et al., 1999; Dubin et al., 1999; Kelley et al., 2003b).

The $5-\mathrm{HT}_{3} \mathrm{R}$ is widely distributed in the central and peripheral nervous systems and on extraneuronal cells, such

ABBREVIATIONS: 5-HT, serotonin; 5- $\mathrm{HT}_{3} \mathrm{R}, 5-\mathrm{HT}$ type 3 receptor; 5- $\mathrm{HT}_{3 \mathrm{~A}} \mathrm{R}, 5-\mathrm{HT}$ type $3 \mathrm{~A}$ receptor; 5- $\mathrm{HT}_{3 \mathrm{AB}} \mathrm{R}, 5-\mathrm{HT}$ type 3AB receptor; $\mathrm{Bup}$, bupropion; cRNA, complementary RNA; $\mathrm{EC}_{30}$, concentration that elicits approximately $30 \%$ of the maximal response; HydroB, hydroxybupropion; nACh, nicotinic acetylcholine; nAChR, nACh receptor; OR-2, oocyte ringer solution. 
as monocytes, chondrocytes, T-cells, and synovial tissue (Fiebich et al., 2004). In the periphery, $5-\mathrm{HT}_{3} \mathrm{Rs}$ are found in the autonomic, sensory, and enteric nervous systems (Faerber et al., 2007), where they are involved in regulating gastrointestinal functions, such as motility, emesis, visceral perception, and secretion (Niesler et al., 2003; Lummis, 2012). The highest density of $5-\mathrm{HT}_{3} \mathrm{Rs}_{\mathrm{s}}$ in the central nervous system is in the hindbrain, particularly the dorsal vagal complex involved in the vomiting reflex, and in limbic structures, notably the amygdala, hippocampus, nucleus accumbens, and striatum (Jones et al., 1992; Miyake et al., 1995). Substantial 5- $\mathrm{HT}_{3 \mathrm{~B}}$ expression was identified in the human brain with high levels in the amygdala, hippocampus, and the nucleus caudate (Dubin et al., 1999; Tzvetkov et al., 2007). A high amount of $5-\mathrm{HT}_{3} \mathrm{Rs}$ are found on presynaptic nerve fibers (Nayak et al., 2000; Miquel et al., 2002), through which they can modulate the release of other neurotransmitters, such as dopamine, cholecystokinin, GABA, substance P, and acetylcholine (Chameau and van Hooft, 2006; Faerber et al., 2007). Owing to its involvement in many brain functions, the $5-\mathrm{HT}_{3} \mathrm{R}$ represents an attractive therapeutic target.

$5-\mathrm{HT}_{3} \mathrm{R}$ antagonists are used to effectively treat patients experiencing irritable bowel syndrome and chemotherapy-/ radiotherapy-induced and postoperative nausea and vomiting (Thompson and Lummis, 2007). Some antidepressants (Choi et al., 2003; Eisensamer et al., 2003) and antipsychotic drugs (Rammes et al., 2004) also antagonize 5- $\mathrm{HT}_{3} \mathrm{Rs}$, which, together with other preclinical and clinical studies, suggests the relevance of $5-\mathrm{HT}_{3} \mathrm{R}$ antagonism for treating psychiatric disorders (Walstab et al., 2010; Bétry et al., 2011). We recently discovered that bupropion (Bup), another antidepressant, antagonizes 5 -HT type $3 \mathrm{~A}$ receptors $\left(5-\mathrm{HT}_{3 \mathrm{~A}} \mathrm{Rs}\right)$ (Pandhare et al., 2017).

Bupropion was first approved as an "atypical" antidepressant over 30 years ago, and today it is one of the most commonly prescribed antidepressants. Despite its recognized clinical efficacy for both depression and smoking cessation, a comprehensive picture of how bupropion modulates neurotransmission is still emerging. Bupropion's therapeutic effect is thought to be mediated by the blocked reuptake of dopamine and norepinephrine (Stahl et al., 2004) and the noncompetitive inhibition of neuronal and muscular AChRs (Slemmer et al., 2000). Most recently, the discovery that bupropion also noncompetitively inhibits $5-\mathrm{HT}_{3 \mathrm{~A}} \mathrm{Rs}$ (Pandhare et al., 2017) raises the questions of whether this inhibition takes place at clinically relevant concentrations and if bupropion also inhibits heteromeric members of the $5-\mathrm{HT}_{3}$ family. Therefore, we investigated the effect of bupropion and its major metabolite, hydroxybupropion (HydroB), on the function of heteromeric $5-\mathrm{HT}_{3 \mathrm{AB}} \mathrm{Rs}$ as compared with the homomeric $5-\mathrm{HT}_{3 \mathrm{~A}} \mathrm{Rs}$ expressed in Xenopus oocytes. Here, we demonstrate that $5-\mathrm{HT}_{3 \mathrm{AB}} \mathrm{Rs}$, like $5-\mathrm{HT}_{3 \mathrm{~A}} \mathrm{Rs}$, are dosedependently inhibited by bupropion and its metabolite. This inhibition is voltage-independent and non-use dependent (i.e., affected by preincubation) and occurs at physiologically relevant concentrations.

\section{Materials and Methods}

Materials. Stock of serotonin (2 mM 5-HT, serotonin creatinine sulfate monohydrate; Acros Organics, New Jersey, NJ) and bupropion (100 mM, Toronto Research Chemicals, Inc., North York, Canada) were
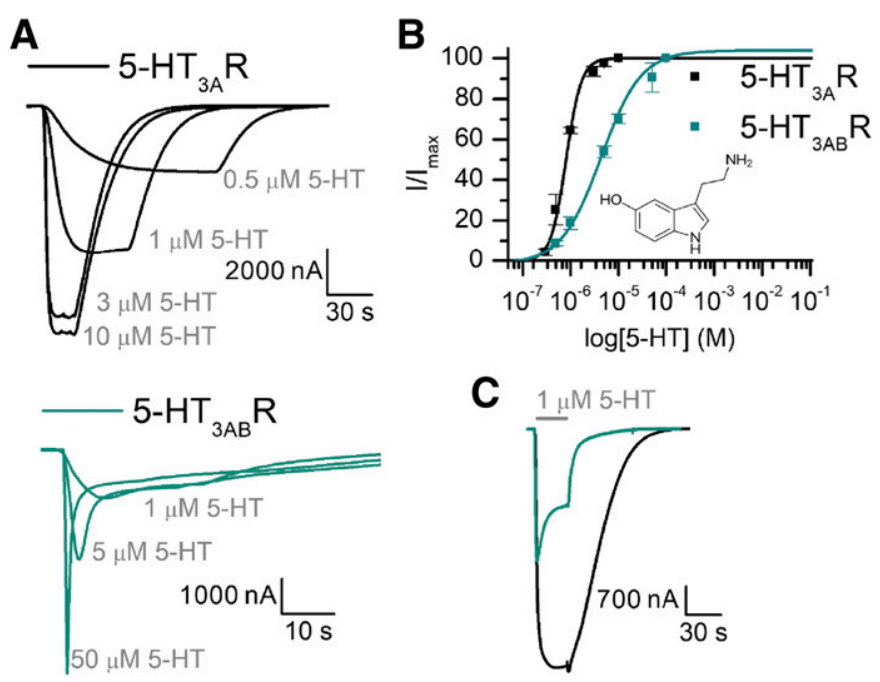

Fig. 1. Comparing $5-\mathrm{HT}_{3 \mathrm{~A}} \mathrm{Rs}$ to $5-\mathrm{HT}_{3 \mathrm{AB}} \mathrm{Rs}$. (A) Sample traces of $5-\mathrm{HT}_{3 \mathrm{~A}}$ (black) and $5-\mathrm{HT}_{3 \mathrm{AB}}$ (green) at varying concentrations of $5-\mathrm{HT}$. (B) Concentration-response curves show a higher potency of $5-\mathrm{HT}$ at $5-\mathrm{HT}_{3 \mathrm{~A}} \mathrm{Rs}$ as compared with $5-\mathrm{HT}_{3 \mathrm{AB}}$, as well as a steeper Hill slope. Parameters from these curves: $5-\mathrm{HT}_{3 \mathrm{~A}}: \mathrm{EC}_{50}=0.8 \mu \mathrm{M}, n_{\mathrm{H}}=2.53 \pm 0.58, n=5,5-\mathrm{HT}_{3 \mathrm{AB}}$ : $\mathrm{EC}_{50}=4.30 \mu \mathrm{M}, n_{\mathrm{H}}=1.04 \pm 0.02, n=8$. Data are represented as the mean \pm S.D. (C) Direct comparison of $5-\mathrm{HT}_{3 \mathrm{~A}}$ and $5-\mathrm{HT}_{3 \mathrm{AB}}$ inward current evoked by $1 \mu \mathrm{M} 5$-HT for 30 seconds.

prepared in distilled water. Hydroxybupropion (100 mM, Toronto Research Chemicals, Inc., North York, Canada) was dissolved in DMSO. All solutions were made in oocyte ringer solution (OR-2) immediately before conducting experiments.

Molecular Biology. Complementary DNA encoding the mouse 5 - $\mathrm{HT}_{3 \mathrm{~A}} \mathrm{R}$ (AAT37716) containing a V5-tag (GKPIPNPLLGLDSTQ) close to the N-terminus (Jansen et al., 2008) and the mouse $5-\mathrm{HT}_{3 \mathrm{~B}}$ receptor (NP_064670) in the pGEMHE vector were used for oocyte expression (Reeves et al., 2001). Plasmids were linearized with the NheI restriction enzyme and in vitro transcribed with the T7 RNA polymerase kit (mMESSAGE mMACHINE T7 Kit; Applied Biosystems/Ambion, Austin, TX). Capped complementary RNA (cRNA) was purified with the MEGAclear Kit (Applied Biosystems/Ambion) and precipitated using $5 \mathrm{M}$ ammonium acetate. cRNA dissolved in nuclease-free water was stored at $-80^{\circ} \mathrm{C}$.

$\boldsymbol{X}$. laevis Oocyte Preparation. Oocytes were isolated, enzymatically defolliculated, and stored as previously described (Goyal et al., 2011). X. laevis frogs were handled and maintained following procedures approved by the local animal welfare committee (Institutional Animal Care and Use Committee, IACUC no. 08014, PHS Assurance no. A 3056-01). In brief, the isolated oocytes were incubated with collagenase (collagenase from Clostridium histolyticum Type IA; Sigma-Aldrich) for 1 hour in OR-2 (115 mM NaCl, $2.5 \mathrm{mM} \mathrm{KCl}$, $1.8 \mathrm{mM} \mathrm{MgCl}_{2}, 10 \mathrm{mM}$ HEPES, $\mathrm{pH} 7.5$ ), which was followed by extensive washing with OR-2. Oocytes were then rinsed three times with OR- $2+2 \mathrm{mM} \mathrm{Ca}^{2+}$ for 45 minutes each and maintained in standard oocyte saline medium [100 mM NaCl, $2 \mathrm{mM} \mathrm{KCl}, 1 \mathrm{mM}$ $\mathrm{MgCl}_{2}, 1.8 \mathrm{mM} \mathrm{CaCl}_{2}, 5 \mathrm{mM}$ HEPES, $\mathrm{pH} 7.5$, supplemented with $1 \%$ Antibiotic-Antimycotic $(100 \times, 10,000 \mathrm{U} / \mathrm{ml}$ of penicillin, $10,000 \mathrm{mg} / \mathrm{ml}$ of streptomycin and $25 \mathrm{mg} / \mathrm{ml}$ amphotericin B; Gibco, Thermo Fisher Scientific), $5 \%$ horse serum] for up to 7 days at $16^{\circ} \mathrm{C}$. Oocytes were microinjected with $10 \mathrm{ng}$ of in vitro synthesized cRNA $(200 \mathrm{ng} / \mu \mathrm{l})$ using an automatic oocyte injector (Nanoject II; Drummond Scientific Co., Broomall, PA) up to 48 hours after isolation. For optimal expression of the heteromeric $5-\mathrm{HT}_{3 \mathrm{AB}} \mathrm{R}$, the A and $\mathrm{B}$ subunits were coinjected in a 1:3 ratio. This ratio has been shown to be optimal for $5-\mathrm{HT}_{3 \mathrm{AB}} \mathrm{R}$ expression because a lower ratio results in $5-\mathrm{HT}_{3 \mathrm{~A}} \mathrm{R}$ mimicked current response and a higher ratio would impact overall receptor expression (Thompson and Lummis, 2013; Corradi et al., 2015). 
A

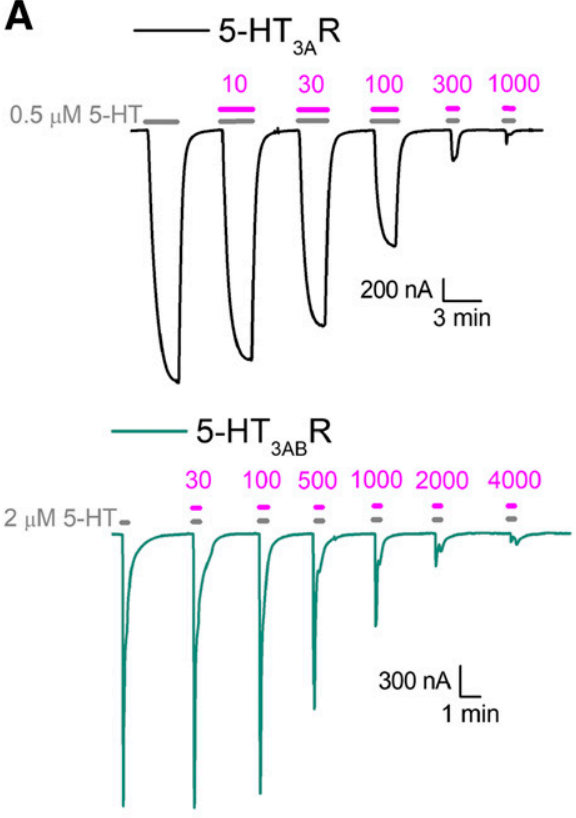

B

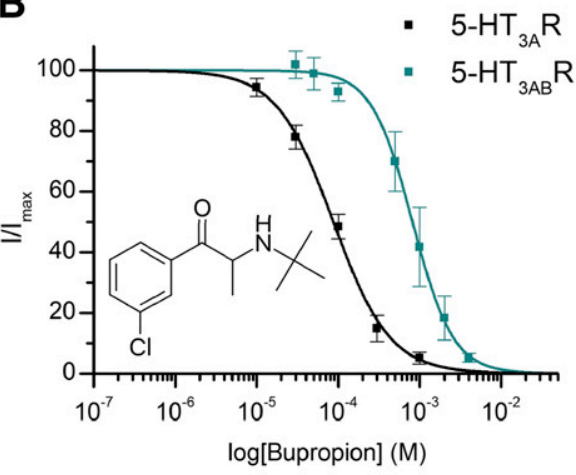

C
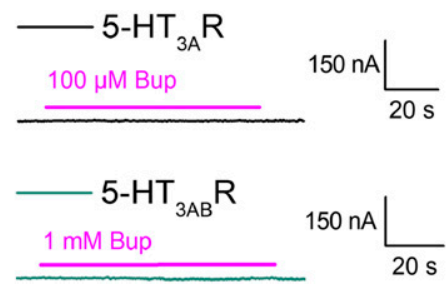

Fig. 2. Bupropion's antagonistic activity at homomeric and heteromeric $5-\mathrm{HT}_{3} \mathrm{Rs}$. (A) Sample traces of oocytes expressing $5-\mathrm{HT}_{3 \mathrm{~A}}$ or $5-\mathrm{HT}_{3 \mathrm{AB}}$ in response to 5 - $\mathrm{HT}\left(\sim \mathrm{EC}_{30}\right)$ alone and in combination with bupropion. 5-HT-evoked inward currents (gray, $5-\mathrm{HT}_{3 \mathrm{~A}}=0.3 \mu \mathrm{M}, 5-\mathrm{HT}_{3 \mathrm{AB}}=2 \mu \mathrm{M}$ ) were used for the control current. Following, the 5-HT concentration was kept constant and coapplied with increasing concentrations of bupropion (5-HT $\left.{ }_{3 \mathrm{~A}}: 10-1000 \mu \mathrm{M}, 5-\mathrm{HT}_{3 \mathrm{AB}}: 30-4000 \mu \mathrm{M}\right)$. (B) Currents were normalized to the control currents and yielded the following $\mathrm{IC}_{50}$ values: 5 $\mathrm{HT}_{3 \mathrm{~A}}: \mathrm{IC}_{50}=87.1 \mu \mathrm{M}\left(\mathrm{n}_{\mathrm{H}}=1.28 \pm 0.15, n=5\right.$, mean \pm S.D. $)$ and $5-\mathrm{HT}_{3 \mathrm{AB}}: \mathrm{IC}_{50}=840 \mu \mathrm{M}\left(\mathrm{n}_{\mathrm{H}}=1.78 \pm\right.$ $0.15, n=7$, mean \pm S.D.). (C) Oocytes expressing $5-\mathrm{HT}_{3 \mathrm{~A}}$ and $5-\mathrm{HT}_{3 \mathrm{AB}}$ did not elicit an inward current in response to bupropion alone.
Electrophysiology. Two-electrode voltage clamp recordings were performed and analyzed using a TEV-200A amplifier (Dagan Instruments, Minneapolis, MN), a Digidata 1440A data interface (Molecular Devices, Sunnyvale, CA), a MiniDigi 1B (Molecular Devices), and the pClamp 10.7 software (Molecular Devices). Recordings were conducted 1-4 days after microinjection. All experiments were performed at room temperature $\left(22-24^{\circ} \mathrm{C}\right)$ and at a holding potential of $-60 \mathrm{mV}$, unless otherwise stated. The oocytes were held in a $250 \mu \mathrm{l}$ chamber and perfused with OR-2 using gravity flow at an approximate rate of $5 \mathrm{ml} / \mathrm{min}$. Drugs and serotonin were dissolved in the same solution and applied by gravity perfusion. The glass microelectrodes were filled with $3 \mathrm{M} \mathrm{KCl}$ and had a resistance of below $2 \mathrm{M} \Omega$. Agonists/antagonists were applied until stable response or desensitization was observed to record maximal current responses.

Data Analysis. All electrophysiological data were analyzed with pClamp, Origin (OriginLab Corporation, Northampton, MA) and GraphPad Prism 6 (GraphPad SoftwareSoft, La Jolla, CA). Data are represented as the mean \pm S.D., and maximal current induced by 5 -HT was used as the normalizing standard (100\% current response) for other current responses in the same oocyte. Statistical significance was determined with paired or unpaired $t$ test (in Origin) with a cutoff for significance of $0.05(* P \leq 0.05$; $* * P \leq 0.01 ; * * * P \leq 0.001)$ or one-way ANOVA followed by Dunnett's multiple comparisons test (in Prism). The 5-HT (agonist stimulation-eq. 1a), bupropion, or hydroxybupropion (antagonist inhibition-eq. 1b) concentration dependence on $5-\mathrm{HT}_{3}$ currents was fitted using the variable-slope sigmoidal dose response curve equations:

$$
\begin{aligned}
\frac{I}{I_{\max }} * 100 & =\frac{1}{1+10^{(\operatorname{LogEC} 50-\mathrm{X})^{*} n_{\mathrm{H}}}} \\
\frac{I}{I_{\max }} * 100 & =\frac{1}{1+10^{(\operatorname{LogIC} 50-\mathrm{X})^{*} n_{\mathrm{H}}}}
\end{aligned}
$$

Within these equations, $I_{\max }$ is the current activated at saturating 5 $\mathrm{HT}$ concentration, $\mathrm{EC}_{50}$ is the agonist concentration producing $50 \%$ of the $I_{\max }, \mathrm{IC}_{50}$ is the concentration of antagonist producing $50 \%$ inhibition of $I_{\max }, \mathrm{X}$ is the logarithm of agonist (eq. 1a) or antagonist (eq. $1 \mathrm{~b}$ ) concentration, and $n_{\mathrm{H}}$ is the Hill coefficient. All figures and graphs were made in Origin and Adobe Illustrator CC 2018.

\section{Results}

Differentiating between $5-\mathbf{H T}_{\mathbf{3 A}} \mathbf{R}$ and $\mathbf{5}-\mathbf{H T}_{\mathbf{3 A B}} \mathbf{R}$. To evaluate the effect of bupropion and its major metabolite hydroxybupropion (Fig. 1) on homomeric and heteromeric $5-\mathrm{HT}_{3}$ receptors, we expressed $5-\mathrm{HT}_{3 \mathrm{~A}} \mathrm{RS}$ and $5-\mathrm{HT}_{3 \mathrm{AB}} \mathrm{RS}$ [in a 1:3 A to B ratio (Thompson and Lummis, 2013; Corradi et al., 2015)] in Xenopus oocytes. First, we substantiated the obvious difference between the two receptor types (Fig. 1). The application of the agonist 5-HT to Xenopus

TABLE 1

$\mathrm{EC}_{50}(5-\mathrm{HT})$ and $\mathrm{IC}_{50}$ values (bupropion and hydroxybupropion) determined in X. laevis oocytes expressing 5- $\mathrm{HT}_{3 \mathrm{~A}} \mathrm{Rs}_{\mathrm{s}}$ and 5$\mathrm{HT}_{3 \mathrm{AB}} \mathrm{Rs}$.

Data represented as mean \pm S.D. of $n$ experiments. Statistical significance of A as compared with $\mathrm{AB}$ was determined with unpaired $t$ test $(* P \leq$ $0.05 ; * * P \leq 0.01 ; * * * P \leq 0.001)$. $\mathrm{pEC}_{50}$ and $\mathrm{pIC}_{50}$ are the negative logarithms of $\mathrm{EC}_{50}$ and $\mathrm{IC}_{50}$, respectively.

\begin{tabular}{lccccc}
\hline & Agonist & $\mathrm{pEC}_{50}(\mu \mathrm{M}$, Mean \pm S.D. $)$ & $\mathrm{EC}_{50}$ & $n_{\mathrm{H}}(\mathrm{Mean} \pm \mathrm{S} . \mathrm{D})$. & $n$ \\
\hline $5-\mathrm{HT}_{3 \mathrm{~A}} \mathrm{R}$ & $5-\mathrm{HT}$ & $6.10 \pm 0.02^{* * *}$ & 0.80 & $2.53 \pm 0.58^{* *}$ & 5 \\
$5-\mathrm{HT}_{3 \mathrm{AB}} \mathrm{R}$ & & $5.38 \pm 0.03^{* * *}$ & 4.30 & $1.04 \pm 0.02^{* *}$ & 4 \\
& & & & & \\
& Antagonist & $\mathrm{pIC}_{50}(\mu \mathrm{M}$, mean \pm S.D. $)$ & $\mathrm{IC}_{50}$ & $n_{\mathrm{H}}(\mathrm{Mean} \pm$ S.D. $)$ & $n$ \\
$5-\mathrm{HT}_{3 \mathrm{~A}} \mathrm{R}$ & Bupropion & $4.06 \pm 0.05^{* * *}$ & 87.1 & $1.28 \pm 0.15^{* * *}$ & 5 \\
$5-\mathrm{HT}_{3 \mathrm{AB}} \mathrm{R}$ & & $3.09 \pm 0.11^{* * *}$ & 840 & $1.78 \pm 0.15^{* * *}$ & 7 \\
$5-\mathrm{HT}_{3 \mathrm{~A}} \mathrm{R}$ & Hydroxybupropion & $3.95 \pm 0.10^{* * *}$ & 113 & $1.17 \pm 0.14^{* * *}$ & 5 \\
$5-\mathrm{HT}_{3 \mathrm{AB}} \mathrm{R}$ & & $3.28 \pm 0.02^{* * *}$ & 526 & $1.80 \pm 0.16^{* * *}$ & 8 \\
\hline
\end{tabular}




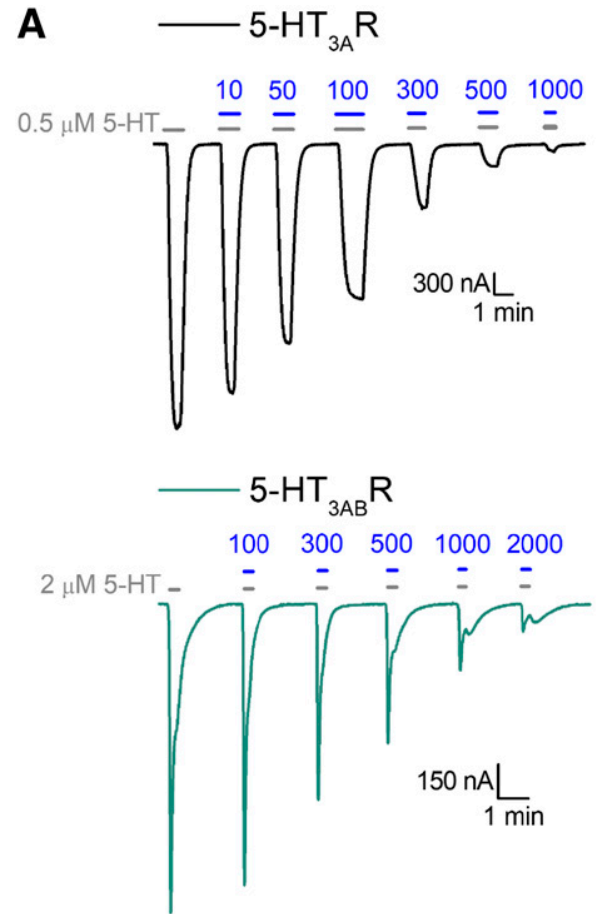

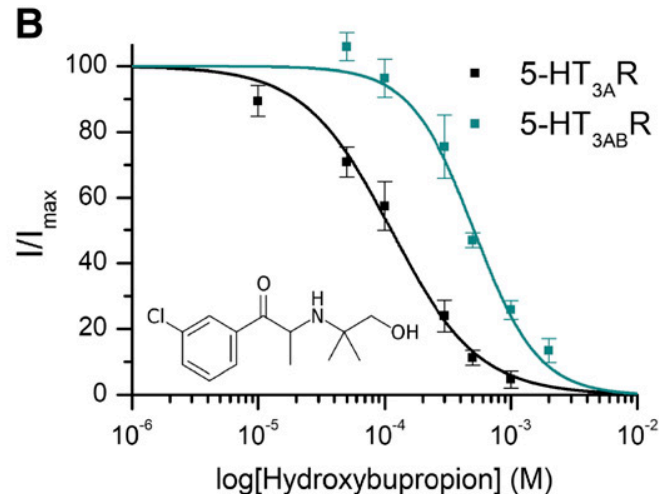

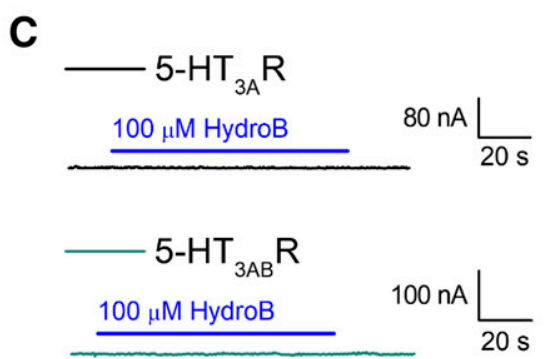

Fig. 3. Hydroxybupropion is an antagonist for $5-\mathrm{HT}_{3 \mathrm{~A}} \mathrm{Rs}$ and $5-\mathrm{HT}_{3 \mathrm{AB}} \mathrm{Rs}$. (A) Sample traces of oocytes expressing 5$\mathrm{HT}_{3 \mathrm{~A}}$ or $5-\mathrm{HT}_{3 \mathrm{AB}}$ in response to $5-\mathrm{HT}$ $\left(\sim \mathrm{EC}_{30}\right)$ alone and in combination with hydroxybupropion. 5-HT-evoked inward currents (gray, $5-\mathrm{HT}_{3 \mathrm{~A}}=0.3 \mu \mathrm{M}, 5-\mathrm{HT}_{3 \mathrm{AB}}$ $=2 \mu \mathrm{M}$ ) were used for the control current. Following, the 5-HT concentration was kept constant and coapplied with increasing concentrations of hydroxybupropion (5- $\mathrm{HT}_{3 \mathrm{~A}}: 10-1000 \mu \mathrm{M}, 5-\mathrm{HT}_{3 \mathrm{AB}}: 50-2000$ $\mu \mathrm{M})$. (B) Currents were normalized to the control currents and yielded the following $\mathrm{IC}_{50}$ values: $5-\mathrm{HT}_{3 \mathrm{~A}}: \mathrm{IC}_{50}=113 \mu \mathrm{M}$ $\left(\mathrm{n}_{\mathrm{H}}=1.17 \pm 0.15, n=5\right.$, mean \pm S.D. $)$ and $5-\mathrm{HT}_{3 \mathrm{AB}}: \mathrm{IC}_{50}=526 \mu \mathrm{M}\left(\mathrm{n}_{\mathrm{H}}=1.80\right.$ $\pm 0.16, n=8$, mean \pm S.D.). (C) Oocytes expressing $5-\mathrm{HT}_{3 \mathrm{~A}}$ and $5-\mathrm{HT}_{3 \mathrm{AB}}$ did not elicit an inward current in response to hydroxybupropion alone. oocytes expressing $5-\mathrm{HT}_{3 \mathrm{~A}} \mathrm{Rs}$ (Fig. $1 \mathrm{~A}$, top trace) or $5-\mathrm{HT}_{3 \mathrm{AB}} \mathrm{Rs}$ (Fig. 1A, bottom trace) elicits a rapid inward current with a concentration-dependent amplitude. The currents resulting from a range of 5 -HT concentrations were used to calculate the concentrations that produce a half-maximal response (Fig. 1B), yielding $\mathrm{EC}_{50}$ values of $0.80 \mu \mathrm{M}\left(n=5\right.$, Hill slope $n_{\mathrm{H}}=2.53 \pm$ $0.58)$ for the $5-\mathrm{HT}_{3 \mathrm{~A}} \mathrm{R}$ and $4.30 \mu \mathrm{M}\left(n=8 ; n_{\mathrm{H}}=1.04 \pm 0.02\right)$ for the $5-\mathrm{HT}_{3 \mathrm{AB}} \mathrm{R}$ (Table 1 ). Our $\mathrm{EC}_{50}$ values are comparable to those reported previously (Jansen et al., 2008; Lochner and Lummis, 2010), with the heteromeric receptor showing a right-shift in potency (Fig. 1B) and fast characteristic desensitization kinetics (Fig. 1C). As reported in the literature, the Hill coefficients are indicative of highly cooperative agonist sites for homopentameric channels and of a single site for heteropentameric channels (Thompson et al., 2011).

Effect of Bupropion on 5-HT ${ }_{3 A} \mathbf{R}$ and $5-H_{\mathbf{H A B}} \mathbf{R}$. 5-HT and a wide range of bupropion concentrations (A: $10-1000 \mu \mathrm{M}$; AB: $30-4000 \mu \mathrm{M})$ were coapplied to Xenopus oocytes expressing homomeric $5-\mathrm{HT}_{3 \mathrm{~A}} \mathrm{Rs}$ (Fig. 2A, top) or heteromeric $5-\mathrm{HT}_{3 \mathrm{AB}} \mathrm{Rs}$ (Fig. 2A, bottom) under two-electrode voltage clamp. 5-HT was applied at concentration that elicits approximately $30 \%$ of the maximal response $\left(\mathrm{EC}_{30}\right)\left(5-\mathrm{HT}_{3 \mathrm{~A}} \mathrm{R}: 0.5 \mu \mathrm{M}, 5-\mathrm{HT}_{3 \mathrm{AB}} \mathrm{R}: 2 \mu \mathrm{M}\right)$. Both traces in Fig. 2A show representative current responses at $-60 \mathrm{mV}$. The first inward current represents the control current evoked by 5-HT alone, and this is followed by subsequent currents obtained by the coapplication of 5-HT $\left(\mathrm{EC}_{30}\right)$ and increasing concentrations of bupropion, which dosedependently inhibited 5-HT-induced currents for $5-\mathrm{HT}_{3 \mathrm{~A}}$ and $5-\mathrm{HT}_{3 \mathrm{AB}}$ receptors. $\mathrm{IC}_{50}$ values were $87.1 \mu \mathrm{M}\left(n_{\mathrm{H}}=1.28 \pm\right.$ $0.15, n=5)$ and $840 \mu \mathrm{M}\left(n_{\mathrm{H}}=1.78 \pm 0.15, n=7\right)$ for $\mathrm{A}$ and $\mathrm{AB}$, respectively (Fig. 2B; Table 1 ). Bupropion's potency at $5-\mathrm{HT}_{3 \mathrm{AB}} \mathrm{R}$ was 10 -fold lower when compared with $5-\mathrm{HT}_{3 \mathrm{~A}} \mathrm{R}$ (unpaired $t$ test, $\mathrm{t}(10)=8.49, P=6.99 \times 10^{-6}$ ). Bupropion alone did not elicit an inward current for either receptor (Fig. 2C).
Effect of Hydroxybupropion on $5-H^{-} T_{3 A} R$ and 5-HT SAB $_{\mathbf{3 A}}$. Hydroxybupropion, a major metabolite of bupropion, is known to contribute to the biologic efficacy of the parent drug because it also inhibits dopamine/norepinephrine transporters, nAChRs, and 5-HT ${ }_{3 \mathrm{~A}} \mathrm{Rs}$ (Bondarev et al., 2003; Damaj et al., 2004; Pandhare et al., 2017). Similar to bupropion, hydroxybupropion inhibited $5-\mathrm{HT}_{3 \mathrm{~A}} \mathrm{Rs}$ and $5-\mathrm{HT}_{3 \mathrm{AB}} \mathrm{Rs}$ dosedependently when coapplied with 5-HT (Fig. 3A). The hydroxybupropion concentrations that reduced the 5-HT-evoked currents to $50 \%$ of the initial response were $113 \mu \mathrm{M}(n=5$, $\left.n_{\mathrm{H}}=1.17 \pm 0.14\right)$ for $5-\mathrm{HT}_{3 \mathrm{~A}} \mathrm{Rs}$ and $526 \mu \mathrm{M}\left(n=8, n_{\mathrm{H}}=1.80 \pm\right.$ 0.16) for 5-HT $\mathrm{HAB}_{3 \mathrm{AB}}$ (Fig. 3B; Table 1). Similar to bupropion, the potency of hydroxybupropion for $5-\mathrm{HT}_{3 \mathrm{AB}} \mathrm{Rs}$ was rightshifted, resulting in a higher $\mathrm{IC}_{50}$ value as compared to $5-\mathrm{HT}_{3 \mathrm{~A}} \mathrm{Rs}$ (unpaired $\mathrm{t}, \mathrm{t}(11)=28.9, P=1.01 \times 10^{-11}$ ). Hydroxybupropion did not elicit a response in $5-\mathrm{HT}_{3 \mathrm{~A}}$ or $5-\mathrm{HT}_{3 \mathrm{AB}}$ expressing oocytes when applied alone (Fig. 3C).

Effect of Preincubation with Bupropion and Hydroxybupropion on 5-HT $\mathbf{T}_{\mathbf{3 A}}$ and 5-HT $\mathbf{T A B}_{\mathbf{3 A B}}$ Receptors. Bupropion's allosteric inhibition of $5-\mathrm{HT}_{3 \mathrm{~A}} \mathrm{Rs}$ is not dependent on the opening of the receptor's channel; it is non-use dependent (Pandhare et al., 2017). To evaluate the extent of inhibition evoked by preincubating oocytes expressing $5-\mathrm{HT}_{3 \mathrm{~A}}$ and $5-\mathrm{HT}_{3 \mathrm{AB}} \mathrm{Rs}$ with bupropion or its metabolite, results were compared to the current amplitudes resulting from coapplication of 5-HT and bupropion/hydroxybupropion. First, oocytes were perfused with $5-\mathrm{HT}\left(\sim \mathrm{EC}_{30}, 5-\mathrm{HT}_{3 \mathrm{~A}} \mathrm{R}: 0.5 \mu \mathrm{M}, 5-\mathrm{HT}_{3 \mathrm{AB}} \mathrm{R}\right.$ : $2 \mu \mathrm{M})$ and bupropion $\left(\sim \mathrm{IC}_{50}, 5-\mathrm{HT}_{3 \mathrm{~A}} \mathrm{R}: 100 \mu \mathrm{M}, 5-\mathrm{HT}_{3 \mathrm{AB}} \mathrm{R}\right.$ : $1 \mathrm{mM}$ ) to obtain the control current (Fig. 4A). Once a stable response was achieved, a constant $\mathrm{IC}_{50}$ concentration of bupropion was exposed to the receptors for exactly $5 \mathrm{~min}$ before another coapplication of the same 5-HT and bupropion solutions. Preincubation decreased the current amplitude of $5-\mathrm{HT}_{3 \mathrm{~A}} \mathrm{Rs}$ to $76.2 \% \pm 7.16 \%$ (Fig. $4 \mathrm{C}$, left panel) of control, consistent with previous findings (Pandhare et al., 2017). On the contrary, under the same experimental conditions, 
the $5-\mathrm{HT}_{3 \mathrm{AB}} \mathrm{R}$ was greatly affected by preincubation, which resulted in a current amplitude reduced to $35.5 \% \pm 5.62 \%$ of the control current (Fig. 4C, right panel). Similar results were obtained from preincubation with hydroxybupropion (Fig. 4B). Compared with coapplication alone, preapplication resulted in a greater depression of current for $5-\mathrm{HT}_{3 \mathrm{~A}} \mathrm{Rs}$ and $5-\mathrm{HT}_{3 \mathrm{AB}} \mathrm{Rs}$ with hydroxybupropion (Fig. $4 \mathrm{C}, 5-\mathrm{HT}_{3 \mathrm{~A}} \mathrm{R}: 93.0 \% \pm 6.12 \%$ and $5-\mathrm{HT}_{3 \mathrm{AB}} \mathrm{R}: 46.1 \% \pm 4.95 \%$ of control current).

Recovery Times for Bupropion Inhibition. Bupropion's antagonistic effect on 5-HT-evoked inward currents has been shown to be reversible (Pandhare et al., 2017). To evaluate the recovery times of bupropion's inhibition of 5-HT-induced currents at homomeric and heteromeric receptors, bupropion was applied to the oocytes for $60 \mathrm{~s}$ at a $400 \mu \mathrm{M}$ concentration. For these experiments, the $\sim \mathrm{EC}_{50}$ concentration of $5-\mathrm{HT}$ (gray bars, 5- $\mathrm{HT}_{3 \mathrm{~A}} \mathrm{R}: 0.8 \mu \mathrm{M}, 5-\mathrm{HT}_{3 \mathrm{AB}} \mathrm{R}: 5.0 \mu \mathrm{M}$ ) was applied episodically after washing in between each application ( $\sim 2 \mathrm{~min})$. These agonist-induced currents led to minimal run-down, and the difference in current amplitudes was less than 10\% (Fig. 5A). Sample traces of current recovery following bupropion application and removal are shown in Fig. 5B (left: black, 5- $\mathrm{HT}_{3 \mathrm{~A}} \mathrm{R}$, right: green, $\left.5-\mathrm{HT}_{3 \mathrm{AB}} \mathrm{R}\right)$. The first current response is the control current evoked by the agonist alone. Once a stable current response was obtained, bupropion was applied without the agonist for $60 \mathrm{~s}$ (magenta bars). Subsequently, the agonist was either applied immediately or after 10, 30, or $60 \mathrm{~s}$ (Fig. $5 \mathrm{~B}$, top trace: $0 \mathrm{~s}$, middle: $30 \mathrm{~s}$, bottom: $60 \mathrm{~s}$ ) after bupropion exposure. The largest decrease in current amplitude for both receptors was immediately after the bupropion application, leaving $82.4 \% \pm 3.08 \%$ and $38.4 \% \pm$ $15.8 \%$ of the initial current for $\mathrm{A}$ and $\mathrm{AB}$, respectively (Fig. 5C). Rapid recovery of current amplitude was achieved by increasing the wash times between bupropion and 5-HT applications. $5-\mathrm{HT}_{3 \mathrm{~A}} \mathrm{Rs}$ and $5-\mathrm{HT}_{3 \mathrm{AB}} \mathrm{Rs}$ both show time-dependent recovery from bupropion inhibition with full reversal after $7+$ min wash time.

Voltage-Independent Binding of Bupropion. To determine if bupropion binds to $5-\mathrm{HT}_{3} \mathrm{Rs}$ in a voltage-dependent manner, 5-HT-induced currents $\left(\sim \mathrm{EC}_{50} ; 5-\mathrm{HT}_{3 \mathrm{~A}} \mathrm{R}: 0.8 \mu \mathrm{M}\right.$; 5- $\mathrm{HT}_{3 \mathrm{AB}} \mathrm{R}: 5.0 \mu \mathrm{M}$ ) were evoked in oocytes expressing 5$\mathrm{HT}_{3 \mathrm{~A}} \mathrm{Rs}$ and $5-\mathrm{HT}_{3 \mathrm{AB}} \mathrm{Rs}$ at two different holding potentials, +40 and $-40 \mathrm{mV}$ (Fig. 6A). First, the control current was obtained at positive and negative voltages before the coapplication of 5-HT and bupropion ( $\sim \mathrm{IC}_{50} ; 5-\mathrm{HT}_{3 \mathrm{~A}} \mathrm{R}: 100 \mu \mathrm{M} ; 5$ $\left.\mathrm{HT}_{3 \mathrm{AB}} \mathrm{R}: 1 \mathrm{mM}\right)$. Bupropion reduced the current amplitudes of homomeric and heteromeric receptors at both voltages. The mean fractional block was recorded at each voltage and normalized to the control current (Fig. 6B; 5- $\mathrm{HT}_{3 \mathrm{~A}} \mathrm{R}: 55.8 \% \pm$ $0.11 \%, 59.8 \% \pm 0.10 \% ; 5-\mathrm{HT}_{3 \mathrm{AB}} \mathrm{R}: 56.6 \% \pm 0.04 \%, 59 \% \pm$ $0.08 \%$; -40 and $+40 \mathrm{mV}$, respectively, $n=4)$. For $5-\mathrm{HT}_{3 \mathrm{~A}} \mathrm{R}$ and $5-\mathrm{HT}_{3 \mathrm{AB}} \mathrm{R}$, this fractional inhibition is similar at positive and negative voltages (paired $t$ test, $3 \mathrm{~A}$ : $\mathrm{t}(3)=1.106, P=0.349$; 3AB: $\mathrm{t}(3)=0.291, P=0.790$ ). Based on these results, inhibition of 5-HT-induced currents by bupropion is independent of voltage.

Bupropion at Physiologic Concentrations and Its Effect on 5-HT $\mathbf{T A}_{\mathbf{3 A}} \mathbf{R}$ and $5-\mathbf{H T}_{\mathbf{3 A B}} \mathbf{R}$. To better understand the clinical significance of the bupropion-induced inhibition of $5-\mathrm{HT}_{3} \mathrm{Rs}, 5$-HT-induced currents were measured in the presence of a clinically relevant bupropion concentration [ 20 $\mu \mathrm{M}$ (Schroeder, 1983; Vázquez-Gómez et al., 2014)]. First, oocytes expressing $5-\mathrm{HT}_{3 \mathrm{~A}} \mathrm{Rs}$ and $5-\mathrm{HT}_{3 \mathrm{AB}} \mathrm{Rs}$ were
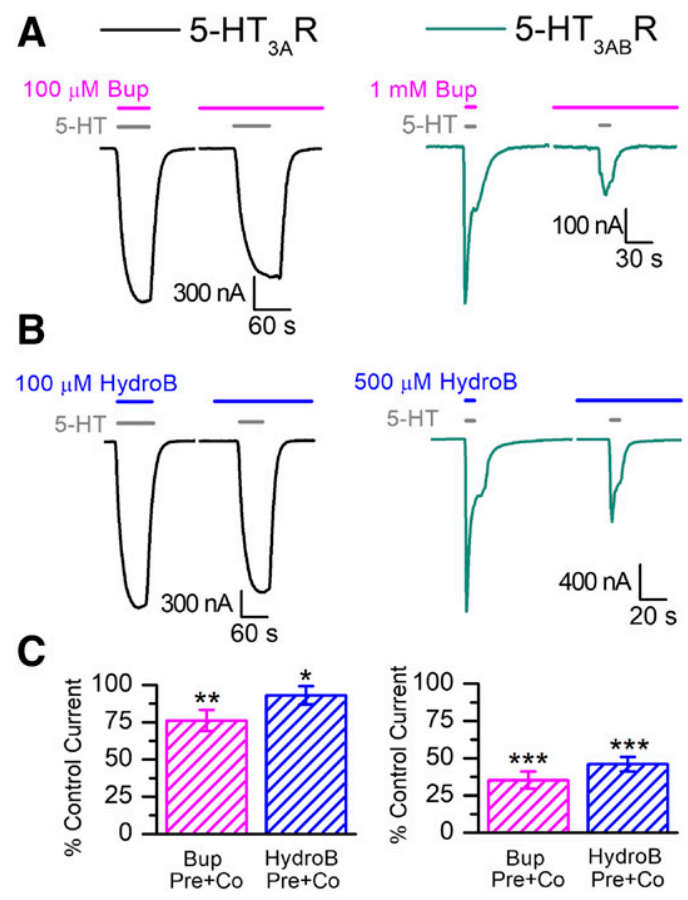

Fig. 4. Non-use dependent allosteric inhibition of $5-\mathrm{HT}_{3 \mathrm{~A}} \mathrm{Rs}$ and 5$\mathrm{HT}_{3 \mathrm{AB}} \mathrm{Rs}$. (A) Sample traces of oocytes expressing 5- $\mathrm{HT}_{3 \mathrm{~A}}$ (black, left panel) and 5- $\mathrm{HT}_{3 \mathrm{AB}}$ (green, right panel). The first 5-HT-evoked currents were used for the control currents (gray bars, $\sim \mathrm{EC}_{30}, 5-\mathrm{HT}_{3 \mathrm{~A}}: 0.5 \mu \mathrm{M}, 5$ $\mathrm{HT}_{3 \mathrm{AB}}: 2 \mu \mathrm{M}$ ) that were obtained by coapplication with bupropion (magenta bars, $\sim \mathrm{IC}_{50}, 5-\mathrm{HT}_{3 \mathrm{~A}}: 100 \mu \mathrm{M}, 5-\mathrm{HT}_{3 \mathrm{AB}}: 1 \mathrm{mM}$ ). Following the stable 5-HT response, bupropion $\left(\sim \mathrm{EC}_{50}\right)$ was perfused for $5 \mathrm{~min}$ before another coapplication of 5-HT and bupropion. (B) Same experimental design as in (A) but with hydroxybupropion (blue bars, $\sim \mathrm{IC}_{50}, 5-\mathrm{HT}_{3 \mathrm{~A}}$ : $100 \mu \mathrm{M}, 5-\mathrm{HT}_{3 \mathrm{AB}}: 500 \mu \mathrm{M}$ ). (C) Quantification of fractional inhibition of currents when the oocyte was preincubated in bupropion (magenta) or hydroxybupropion (blue) normalized to the control current (100\%). Preincubation reduced current amplitudes for $5-\mathrm{HT}_{3 \mathrm{~A}}$ (Bup: $76.1 \% \pm 7.16 \%$, $n=5$; HydroB: $93.0 \% \pm 6.12 \%, n=6$ ) and $5-\mathrm{HT}_{3 \mathrm{AB}}$ (Bup: $35.5 \% \pm 5.62 \%$, $n=6$; HydroB: $46.1 \% \pm 4.95 \%, n=4)$ as compared with coapplication. Statistical significance was determined with paired $t$ test $(* P \leq 0.05 ; * * P \leq$ 0.01 ; $* * * P \leq 0.001$ ), comparing coapplication (representing $100 \%$ of the current) to preapplication + coapplication (Pre $+\mathrm{Co})$ with each drug independently. Data are represented as the mean \pm S.D.

exposed to three different 5 -HT concentrations $(0.5,1.0$, $5.0 \mu \mathrm{M})$ in the absence of bupropion to obtain the initial current amplitudes (Fig. 7A, black, left panel: $5-\mathrm{HT}_{3 \mathrm{~A}} \mathrm{R}$, green, right panel: $\left.5-\mathrm{HT}_{3 \mathrm{AB}} \mathrm{R}\right)$. Next, the oocytes were continuously perfused with $20 \mu \mathrm{M}$ bupropion, and the same 5 -HT concentrations were reapplied; the oocytes were preincubated with bupropion for at least 2 minprior to 5-HT application (Fig. 7A, magenta bars indicating bupropion presence). The results indicate that the continuous presence of a low concentration of bupropion in the bath solution partially inhibits 5$\mathrm{HT}$-induced currents of $5-\mathrm{HT}_{3 \mathrm{~A}} \mathrm{Rs}$ and $5-\mathrm{HT}_{3 \mathrm{AB}} \mathrm{Rs}$ at all $5-\mathrm{HT}$ concentrations tested (Fig. 7B, paired $t$ test, $P \leq 0.05$ or lower). Bupropion inhibited 5-HT-induced currents by $\sim 18 \%$ for $5-\mathrm{HT}_{3 \mathrm{~A}} \mathrm{Rs}(n=4)$, whereas $5-\mathrm{HT}_{3 \mathrm{AB}} \mathrm{Rs}$ showed a $\sim 23 \%$ decrease in current $(n=5$, Fig. $7 \mathrm{~B})$.

\section{Discussion}

Our results, for the first time, demonstrate that bupropion antagonizes heteromeric $5-\mathrm{HT}_{3 \mathrm{AB}}$ receptors and that the kinetics of inhibition are distinct from 5 - $\mathrm{HT}_{3 \mathrm{~A}}$. Two-electrode voltage clamp experiments indicate that bupropion reversibly 
A

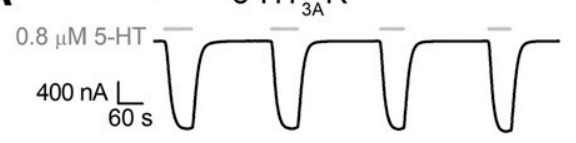

B

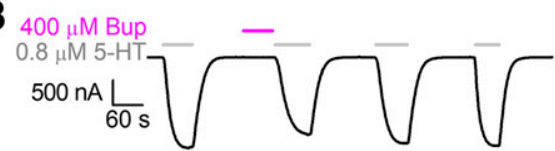

$400 \mu \mathrm{M}$ Bup

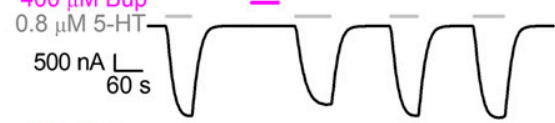

$400 \mu \mathrm{M}$ Bup

$0.8 \mu \mathrm{M} 5-\mathrm{H}^{\mathrm{H}}$

$2 \mu \mathrm{A}$
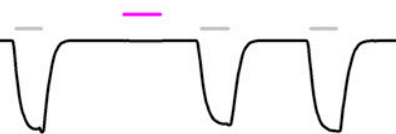

C

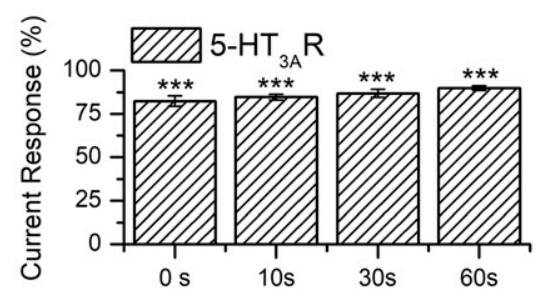

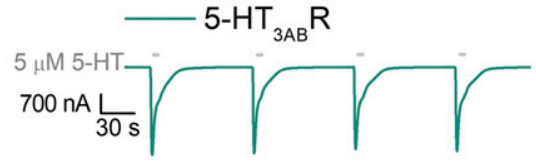
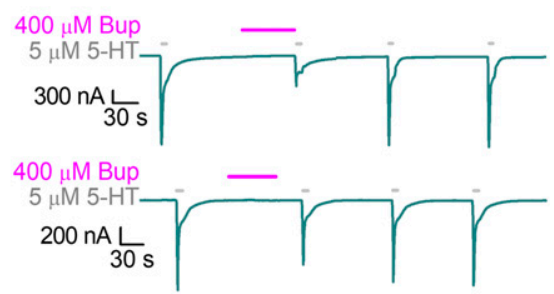

$400 \mu \mathrm{M}$ Bup
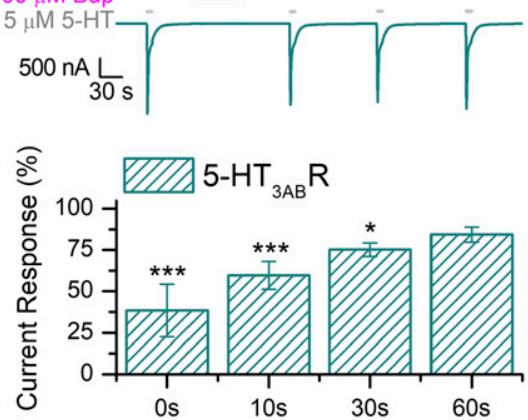

Fig. 5. Recovery times for bupropion. (A and B) Sample traces of bupropion application (magenta bar) and the recovery times for $5-\mathrm{HT}_{3 \mathrm{~A}}$ (left panel, black) and 5-HT $3 \mathrm{AB}$ (right panel, green). (A) In two-electrode voltage clamp experiments, oocytes expressing $5-\mathrm{HT}_{3 \mathrm{~A}}$ and $5-\mathrm{HT}_{3 \mathrm{AB}}$ showed a stable response to repeated applications of 0.8 and $5 \mu \mathrm{M} 5-\mathrm{HT}$ at $-60 \mathrm{mV}$, with an approximate wash time of $2 \mathrm{~min}$. (B) The first 5-HT-evoked response represents the control current for the recovery experiment. Bupropion $(400 \mu \mathrm{M})$ was applied alone for $60 \mathrm{~s}$ at $-60 \mathrm{mV}$, followed by an immediate application of 5-HT. The gray and magenta bars represent the time of application of 5-HT and bupropion, respectively. Moving down the panel, the wash times after bupropion application were 0,30 , and $60 \mathrm{~s}$. (C) Quantitative representation of current amplitudes and results in (B) $(n=3) .5-\mathrm{HT}_{3 \mathrm{~A}}$ was maximally reduced to $82.4 \% \pm 3.08 \%$ and $5-\mathrm{HT}_{3 \mathrm{AB}}$ to $38.4 \% \pm 15.8 \%$ of the control current when the agonist was applied immediately after bupropion, followed by a stepwise recovery. All currents could be recovered to $\sim 95 \%$ after $\sim 7.5$-min wash. Statistical significance of each wash time as compared with the control current (the 5-HT-induced current response before exposure to Bup or HydroB) was determined with one-way ANOVA, Dunnett's multiple comparisons test $(* P \leq 0.05$; *** $P \leq$ 0.001). Data are represented as the mean \pm S.D. inhibits 5-HT-induced currents of Xenopus oocytes expressing $5-\mathrm{HT}_{3 \mathrm{~A}}$ and $5-\mathrm{HT}_{3 \mathrm{AB}} \mathrm{Rs}$ in a concentration-dependent manner, with inhibitory potencies of $87.1 \mu \mathrm{M}$ [same as previously reported (Pandhare et al., 2017)] and $840 \mu \mathrm{M}$, respectively.
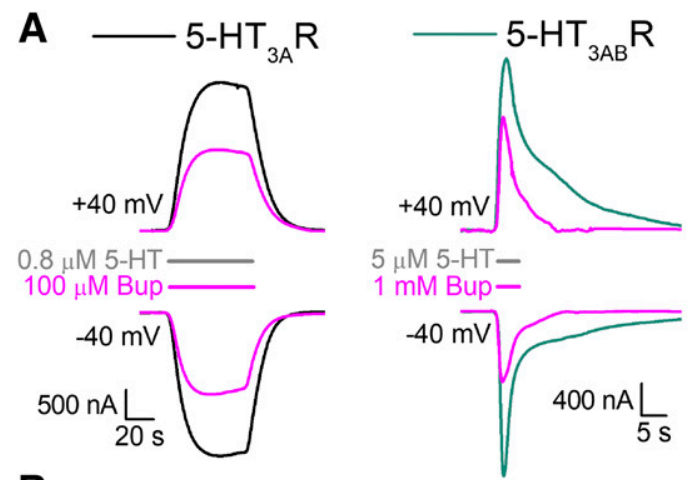

B
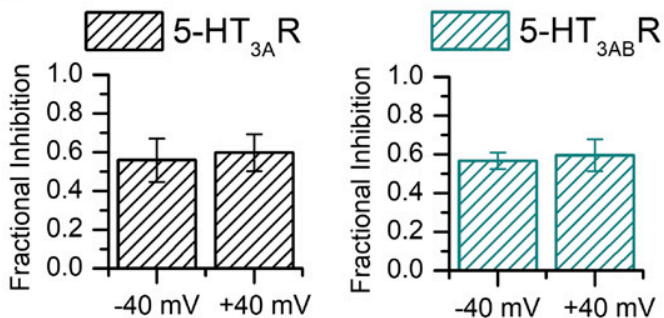

Fig. 6. Voltage-independent block of $5-\mathrm{HT}_{3}-$ mediated currents by bupropion. (A) Sample traces of 5- $\mathrm{HT}_{3 \mathrm{~A}^{-}}$and $5-\mathrm{HT}_{3 \mathrm{AB}}-$ expressing oocytes (5$\mathrm{HT}_{3 \mathrm{~A}}$ : left, black; 5- $\mathrm{HT}_{3 \mathrm{AB}}$ : right, green) in response to 5-HT ( $\mathrm{EC}_{50}$; top and bottom traces, $\left.5-\mathrm{HT}_{3 \mathrm{~A}}: 0.8 \mu \mathrm{M} ; 5-\mathrm{HT}_{3 \mathrm{AB}}: 5.0 \mu \mathrm{M}\right)$ in the absence and presence of bupropion (magenta traces, $\sim \mathrm{IC}_{50} ; 5-\mathrm{HT}_{3 \mathrm{~A}}: 100 \mu \mathrm{M} ; 5-\mathrm{HT}_{3 \mathrm{AB}}$ : $1 \mathrm{mM}$ ) at different voltages. (B) Quantification of fractional inhibition, currents were normalized to the control currents at each voltage $(n=4)$. Data are shown as mean \pm S.D. Statistical significance between the inhibition at positive and negative voltages was determined with paired $t$ test $(* P \leq 0.05 ; * * P \leq 0.01 ; * * * P \leq 0.001)$.
Similar to other noncompetitive antagonists [such as picrotoxin (Das and Dillon, 2003)], bupropion has a lower potency ( 10-fold) at $5-\mathrm{HT}_{3 \mathrm{AB}}$ as compared to $5-\mathrm{HT}_{3 \mathrm{~A}}$ receptors and, therefore, could be used to discriminate between these two receptors (Thompson and Lummis, 2013).

Similarly to bupropion, the metabolite inhibits nAChRs and $5-\mathrm{HT}_{3 \mathrm{~A}} \mathrm{Rs}$ in a noncompetitive manner (Damaj et al., 2004; Pandhare et al., 2017) and also shares a comparable potency (unpaired $t$ test, $P$ value $=0.06704$ ) for the homomeric receptor $\left[5-\mathrm{HT}_{3 \mathrm{~A}} \mathrm{R}\right.$ : $\mathrm{IC}_{50}=113 \mu \mathrm{M}$, similar to previously reported data (Pandhare et al., 2017)]. Hydroxybupropion exhibits a $\sim 4.5$-fold shift in $\mathrm{IC}_{50}$ for the heteromeric channel $\left(5-\mathrm{HT}_{3 \mathrm{AB}} \mathrm{R}: \mathrm{IC}_{50}=526 \mu \mathrm{M}\right)$. The estimated Hill slopes $\left(n_{\mathrm{H}}\right.$ values) for both bupropion and hydroxybupropion for both receptors were greater than unity (1.17-1.80), suggesting the presence of multiple binding sites with a cooperative mechanism. The Hill coefficients for the $5-\mathrm{HT}_{3 \mathrm{AB}} \mathrm{R}$ were 1.4 times larger for both bupropion and hydroxybuporpion as compared with for the $5-\mathrm{HT}_{3 \mathrm{~A}} \mathrm{R}$, which may indicate a concerted conformational change or cooperativity of binding (Colquhoun, 1998).

Bupropion-mediated inhibition of $5-\mathrm{HT}_{3 \mathrm{~A}} \mathrm{Rs}$ is non-use dependent (Pandhare et al., 2017). In general, use-dependent block, or inhibition that would require a channel to be open to occur, is not influenced by preapplication. We evaluated the effect of a 5-min preincubation with bupropion and its metabolite hydroxybupropion on the homomeric and the heteromeric receptor (Fig. 4). Preincubation with antagonistled to an increased inhibition in all cases when compared with coapplication, indicating that the block is non-use dependent for both receptors. Our observation that bupropion's inhibition of $5-\mathrm{HT}_{3} \mathrm{Rs}$ is voltage-independent additionally concurs with it not acting as an open channel blocker (Slemmer et al., 2000; Choi et al., 2003; Gumilar et al., 2003). Similar results are shown with other antidepressants at $5-\mathrm{HT}_{3} \mathrm{Rs}$ (Eisensamer et al., 2003) and with bupropion at nAChRs 

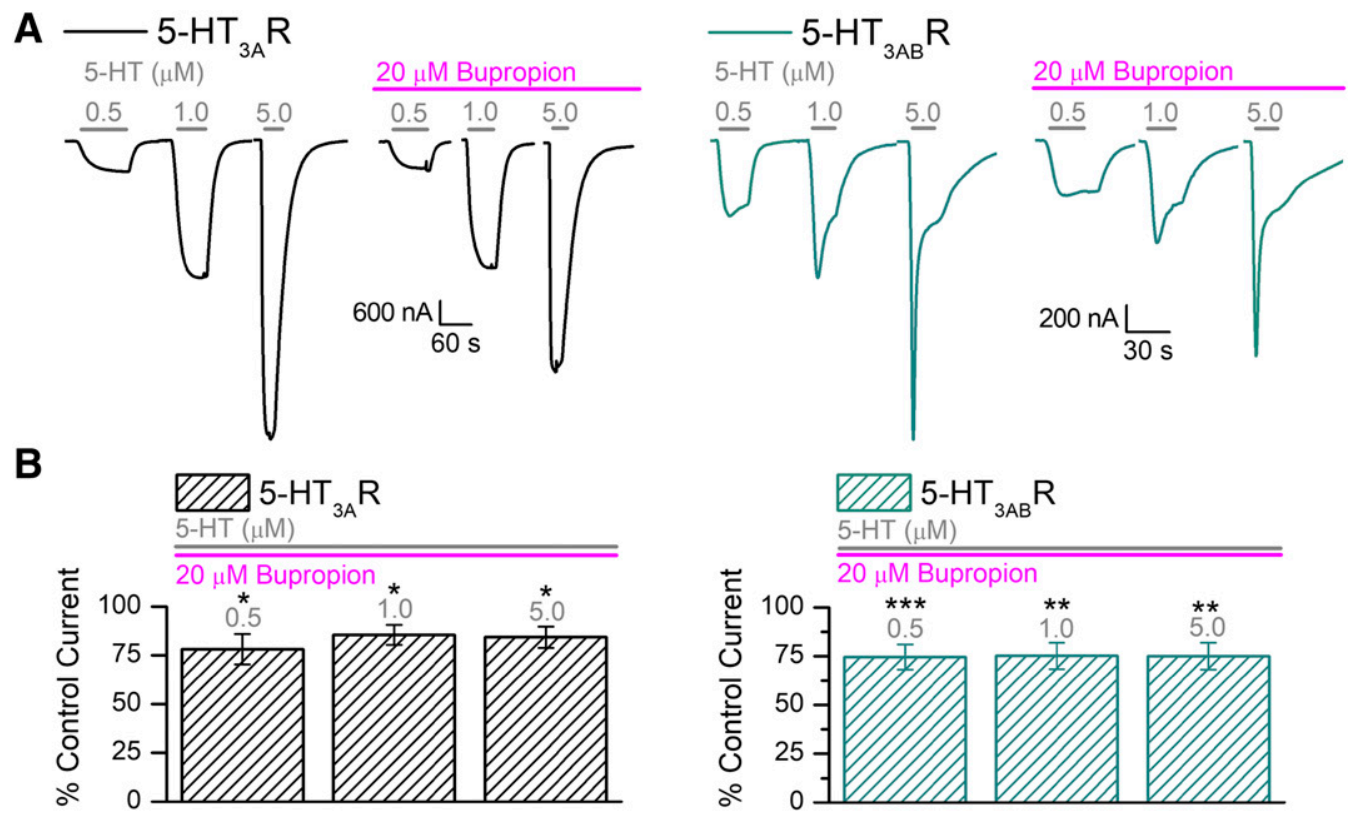

Fig. 7. Bupropion at clinically achievable concentrations and its effect on 5 - $\mathrm{HT}_{3 \mathrm{~A}} \mathrm{Rs}$ and 5 - $\mathrm{HT}_{3 \mathrm{AB}} \mathrm{Rs}$. (A) Sample traces of oocytes expressing 5 - $\mathrm{HT} \mathrm{T}_{3 \mathrm{~A}}$ (black, left panel) and 5- $\mathrm{HT}_{3 \mathrm{AB}}$ (green, right panel) in response to $0.5,1.0$, and $5.0 \mu \mathrm{M} 5$ - $\mathrm{HT}$ (gray bars) followed by the same concentrations coapplied with $20 \mu \mathrm{M}$ bupropion. Following the initial exposure to the three 5-HT concentrations (control current), the oocytes were exposed to $20 \mu \mathrm{M}$ bupropion for at least 2 min before coapplication with the agonist. (B) Quantitative representation of current amplitudes and results in (A) (A: $n=4, \mathrm{AB}: n=5)$. Data are shown as mean \pm S.D. Statistical significance between each 5 -HT concentration without and with bupropion at the same 5-HT concentration was determined with paired $t$ test $(* P \leq 0.05 ; * * P \leq 0.01 ; * * P \leq 0.001)$.

(e.g., $\left.\alpha_{3} \beta_{2}, \alpha_{4} \beta_{2}, \alpha_{3} \beta_{4}\right)$ with predictions for an external binding site for bupropion (Slemmer et al., 2000; GarcíaColunga et al., 2011). Considering different binding sites within the family of AChRs (Pandhare et al., 2012), bupropion may have distinct binding sites in each channel (Arias et al., 2009).

We saw a greater depression of current amplitudes when bupropion or its metabolite was preincubated as compared with coapplication with 5-HT [Fig. 5, 5- $\mathrm{HT}_{3 \mathrm{~A}} \mathrm{R}: 76.2 \% \pm$ $7.16 \%, 93.0 \% \pm 6.12 \%$; $5-\mathrm{HT}_{3 \mathrm{AB}} \mathrm{R}: 35.5 \% \pm 5.62 \%, 46.1 \% \pm$ $4.95 \%$ of control current, Bup and HydroB, respectively]. During the preincubation experiments, bupropion binds and inhibits the receptor prior to the opening of the channel, therefore presumably interacting with the closed channel and potentially inhibiting the channel from opening (Choi et al., 2003; Arias et al., 2009). Consistent with other data, greater potencies of inhibition have been reported for bupropion and tricyclic antidepressants on Cys-loop receptors in the resting state than the open state (Choi et al., 2003; Gumilar and Bouzat, 2008; Arias et al., 2009). This phenomenon may be due to the accumulation of antidepressants and antipsychotics in the cell membrane during preincubation, which may be important for the functional antagonistic effects of these drugs at the $5-\mathrm{HT}_{3}$ receptor (Eisensamer et al., 2005). Overall, this may indicate that bupropion has access to its binding site(s) from the membrane environment. We find that inhibition after preincubation is more pronounced in the $5-\mathrm{HT}_{3 \mathrm{AB}}$ as compared with the $5-\mathrm{HT}_{3 \mathrm{~A}}$ receptor.

Bupropion's inhibition of 5-HT-mediated currents is reversible after a substantial amount of washing. In this study, we investigated the time it takes for $5-\mathrm{HT}_{3} \mathrm{R}$ to recover from preincubation with bupropion at high concentrations $(400 \mu \mathrm{M}$ Bup). Similar to our preincubation experiments, bupropion reduced $5-\mathrm{HT}_{3 \mathrm{~A}} \mathrm{R}$ currents but to a lesser extent than $5-\mathrm{HT}_{3 \mathrm{AB}} \mathrm{R}$ currents. The largest reduction of current was observed with the shortest amount of wash time between the bupropion and agonist applications $\left(5-\mathrm{HT}_{3 \mathrm{~A}} \mathrm{R}: 82.4 \% \pm 3.08 \% ; 5-\mathrm{HT}_{3 \mathrm{AB}} \mathrm{R}\right.$ : $38.4 \% \pm 15.8 \%$ of the control current after 0 -s wash). $5-\mathrm{HT}_{3 \mathrm{~A}}$ and $5-\mathrm{HT}_{3 \mathrm{AB}}$ receptors show a time-dependent recovery from bupropion's inhibition, and their currents could be fully recovered after $\sim 7.5 \mathrm{~min}$ of washing.

The clinical relevance of $5-\mathrm{HT}_{3}$ inhibition by bupropion is currently unknown. Bupropion, but not its metabolites, concentrates in many tissues with a brain to plasma ratio of 25:1 (Schroeder, 1983), which results in brain concentrations of $\sim 20 \mu \mathrm{M}$ (Vázquez-Gómez et al., 2014). Coapplication of $20 \mu \mathrm{M}$ bupropion with agonist minimally inhibits 5-HT-induced currents of $5-\mathrm{HT}_{3 \mathrm{~A}} \mathrm{Rs}$ and does not affect $\mathrm{HT}_{3 \mathrm{AB}} \mathrm{Rs}$. On the contrary, preincubation with bupropion has a drastic impact on its inhibitory effect (Fig. 7). Our results indicate that a preincubation time of $5 \mathrm{~min}$ with $20 \mu \mathrm{M}$ bupropion is enough to inhibit $5-\mathrm{HT}_{3}$ receptors $\left(5-\mathrm{HT}_{3 \mathrm{~A}} \mathrm{R}: \sim 82.7 \% \quad 5-\mathrm{HT}_{3 \mathrm{AB}} \mathrm{R}\right.$ : $\sim 74.9 \%$ of control current). Moreover, hydroxybupropion reaches $\sim 10$-fold higher plasma concentrations in humans as compared with the parent drug (Findlay et al., 1981; Hsyu et al., 1997). With an average of $\sim 100 \mu \mathrm{M}$ (based on clinical data, test ID: FBUMT; Mayo Clinic, MN), hydroxybupropion's plasma concentrations are equivalent to $5-\mathrm{HT}_{3 \mathrm{~A}} \mathrm{R}$ 's $\mathrm{IC}_{50}$ value. Additionally, considering the increased inhibitory effect due to preincubation of $5-\mathrm{HT}_{3} \mathrm{Rs}$, we conclude that bupropion and hydroxybupropion have the potential to inhibit these receptors at clinically attainable concentrations.

The comprehensive mechanism by which bupropion achieves its therapeutic efficacy is multifactorial. At therapeutic dosages, bupropion inhibits nACh receptors in the ventral tegmental area, dorsal raphe nucleus neurons, and interneurons in the hippocampal CA1 area (Alkondon and Albuquerque, 2005; Vázquez-Gómez et al., 2014). There, nAChRs can modulate 
serotonergic projections (Aznar et al., 2005; Chang et al., 2011) and alter GABAergic transmission (Ji and Dani, 2000), in turn increasing dopamine levels, contributing to bupropion's antidepressant activity (Arias, 2009; VázquezGómez et al., 2014). 5- $\mathrm{HT}_{3}$ receptors also show strong interactions with GABAergic neurons in the hippocampus and neocortical cells (Morales et al., 1996) and mediate stress-dependent activation of dopaminergic neurotransmission (Devadoss et al., 2010; Bhatt et al., 2013). Animal studies have demonstrated that $5-\mathrm{HT}_{3}$ antagonists have anxiolytic activity, possibly because of the inhibition of limbic hyperactivity responses (Bhatt et al., 2013), and this is supported by the finding that $5-\mathrm{HT}_{3 \mathrm{~A}} \mathrm{R}$ gene deletion produces an anxiolytic phenotype in mice (Kelley et al., 2003a). Furthermore, 5- $\mathrm{HT}_{3}$ antagonists have implications on hippocampal long-term potentiation (Bétry et al., 2011), increase synaptic norepinephrine levels, facilitate 5-HT neurotransmission of other 5 -HT receptors (Rajkumar and Mahesh, 2010), and even enhance the antidepressant action of bupropion (Devadoss et al., 2010).

In conclusion, $5-\mathrm{HT}_{3}$ and $\mathrm{nACh}$ receptors have shown many implications in the neurobiology of depression and a highly complex interplay can be expected between these systems. Currently, it is not known if bupropion- or hydroxybupropionmediated inhibition of $5-\mathrm{HT}_{3}$ receptors is clinically relevant for their antidepressant activity. Further studies focused on characterizing bupropion's accumulation in membranes, identification of its binding sites, and delineation of its molecular mechanism of action are warranted. We show here that bupropion inhibits $5-\mathrm{HT}_{3}$ receptors at clinically relevant concentrations and that this inhibition may contribute to bupropion's clinical effects.

\section{Acknowledgments}

We thank Dr. Myles Akabas (Einstein, NY) for providing us with the $5-\mathrm{HT}_{3}$ plasmids. We thank the Texas Tech University Health Sciences Center (TTUHSC) Core Facilities: some of the images and/or data were generated in the Image Analysis Core Facility \& Molecular Biology Core Facility supported by TTUHSC.

\section{Authorship Contributions}

Participated in research design: Stuebler, Jansen.

Conducted experiments: Stuebler.

Performed data analysis: Stuebler, Jansen.

Wrote or contributed to the writing of the manuscript: Stuebler, Jansen.

\section{References}

Alkondon M and Albuquerque EX (2005) Nicotinic receptor subtypes in rat hippocampal slices are differentially sensitive to desensitization and early in vivo functional up-regulation by nicotine and to block by bupropion. J Pharmacol Exp Ther 313:740-750

Arias HR (2009) Is the inhibition of nicotinic acetylcholine receptors by bupropion involved in its clinical actions? Int J Biochem Cell Biol 41:2098-2108.

Arias HR, Gumilar F, Rosenberg A, Targowska-Duda KM, Feuerbach D, Jozwiak K, Moaddel R, Wainer IW, and Bouzat C (2009) Interaction of bupropion with muscletype nicotinic acetylcholine receptors in different conformational states. Biochemistry 48:4506-4518.

Aznar S, Kostova V, Christiansen SH, and Knudsen GM (2005) Alpha 7 nicotinic receptor subunit is present on serotonin neurons projecting to hippocampus and septum. Synapse 55:196-200.

Bétry C, Etiévant A, Oosterhof C, Ebert B, Sanchez C, and Haddjeri N (2011) Role of 5 -HT(3) receptors in the antidepressant response. Pharmaceuticals (Basel) 4 603-629.

Bhatt S, Mahesh R, Devadoss T, and Jindal AK (2013) Antidepressant-like effect of novel 5-HT3 receptor antagonist N-n-butyl-3-ethoxyquinoxalin-2-carboxamide (6p): an approach using rodent behavioral antidepressant tests. Indian J Pharmacol $\mathbf{4 5}$ 348-353.

Bondarev ML, Bondareva TS, Young R, and Glennon RA (2003) Behavioral and biochemical investigations of bupropion metabolites. Eur J Pharmacol 474:85-93.
Chameau P and van Hooft JA (2006) Serotonin 5-HT(3) receptors in the central nervous system. Cell Tissue Res 326:573-581.

Chang B, Daniele CA, Gallagher K, Madonia M, Mitchum RD, Barrett L, Vezina P, and McGehee DS (2011) Nicotinic excitation of serotonergic projections from dorsal raphe to the nucleus accumbens. J Neurophysiol 106:801-808.

Choi JS, Choi BH, Ahn HS, Kim MJ, Rhie DJ, Yoon SH, Min DS, Jo YH, Kim MS, Sung KW, et al. (2003) Mechanism of block by fluoxetine of 5-hydroxytryptamine3 (5-HT3)-mediated currents in NCB-20 neuroblastoma cells. Biochem Pharmacol 66:2125-2132.

Colquhoun D (1998) Binding, gating, affinity and efficacy: the interpretation of structure-activity relationships for agonists and of the effects of mutating receptors. Br J Pharmacol 125:924-947.

Corradi J, Thompson AJ, McGonigle I, Price KL, Bouzat C, and Lummis SC (2015) 5HT3 receptor brain-type B-subunits are differentially expressed in heterologous systems. ACS Chem Neurosci 6:1158-1164.

Damaj MI, Carroll FI, Eaton JB, Navarro HA, Blough BE, Mirza S, Lukas RJ, and Martin BR (2004) Enantioselective effects of hydroxy metabolites of bupropion on behavior and on function of monoamine transporters and nicotinic receptors. Mol Pharmacol 66:675-682.

Das P and Dillon GH (2003) The 5-HT3B subunit confers reduced sensitivity to picrotoxin when co-expressed with the 5-HT3A receptor. Brain Res Mol Brain Res 119:207-212.

Davies PA, Pistis M, Hanna MC, Peters JA, Lambert JJ, Hales TG, and Kirkness EF (1999) The 5-HT3B subunit is a major determinant of serotonin-receptor function. Nature 397:359-363.

Devadoss T, Pandey DK, Mahesh R, and Yadav SK (2010) Effect of acute and chronic treatment with QCF-3 (4-benzylpiperazin-1-yl) (quinoxalin-2-yl) methanone, a novel 5-HT(3) receptor antagonist, in animal models of depression. Pharmacol Rep 62:245-257.

Dubin AE, Huvar R, D’Andrea MR, Pyati J, Zhu JY, Joy KC, Wilson SJ, Galindo JE, Glass CA, Luo L, et al. (1999) The pharmacological and functional characteristics of the serotonin $5-\mathrm{HT}(3 \mathrm{~A})$ receptor are specifically modified by a $5-\mathrm{HT}(3 \mathrm{~B})$ receptor subunit. J Biol Chem 274:30799-30810.

Eisensamer B, Rammes G, Gimpl G, Shapa M, Ferrari U, Hapfelmeier G, Bondy B, Parsons C, Gilling K, Zieglgänsberger W, et al. (2003) Antidepressants are functional antagonists at the serotonin type 3 (5-HT3) receptor. Mol Psychiatry 8: 994-1007.

Eisensamer B, Uhr M, Meyr S, Gimpl G, Deiml T, Rammes G, Lambert JJ, Zieglgänsberger W, Holsboer F, and Rupprecht R (2005) Antidepressants and antipsychotic drugs colocalize with 5 -HT3 receptors in raft-like domains. J Neurosci 25: 10198-10206.

Faerber L, Drechsler S, Ladenburger S, Gschaidmeier H, and Fischer W (2007) The neuronal 5-HT3 receptor network after 20 years of research--evolving concepts in management of pain and inflammation. Eur J Pharmacol 560:1-8.

Fiebich BL, Akundi RS, Seidel M, Geyer V, Haus U, Müller W, Stratz T, and Candelario-Jalil E (2004) Expression of 5-HT3A receptors in cells of the immune system. Scand J Rheumatol Suppl 119:9-11.

Findlay JW, Van Wyck Fleet J, Smith PG, Butz RF, Hinton ML, Blum MR, and Schroeder DH (1981) Pharmacokinetics of bupropion, a novel antidepressant agent, following oral administration to healthy subjects. Eur J Clin Pharmacol 21 127-135.

García-Colunga J, Godoy-García U, and Vázquez-Gómez E (2011) Interaction of bupropion and zinc with neuronal nicotinic acetylcholine receptors. Neuropharmacology 61:1202-1209.

Goyal R, Salahudeen AA, and Jansen M (2011) Engineering a prokaryotic Cys-loop receptor with a third functional domain. J Biol Chem 286:34635-34642.

Gumilar F, Arias HR, Spitzmaul G, and Bouzat C (2003) Molecular mechanisms of inhibition of nicotinic acetylcholine receptors by tricyclic antidepressants. Neuropharmacology 45:964-976.

Gumilar F and Bouzat C (2008) Tricyclic antidepressants inhibit homomeric Cys-loop receptors by acting at different conformational states. Eur J Pharmacol 584:30-39.

Hassaine G, Deluz C, Grasso L, Wyss R, Tol MB, Hovius R, Graff A, Stahlberg H, Tomizaki T, Desmyter A, et al. (2014) X-ray structure of the mouse serotonin 5HT3 receptor. Nature 512:276-281.

Hsyu PH, Singh A, Giargiari TD, Dunn JA, Ascher JA, and Johnston JA (1997) Pharmacokinetics of bupropion and its metabolites in cigarette smokers versus nonsmokers. J Clin Pharmacol 37:737-743.

Hussy N, Lukas W, and Jones KA (1994) Functional properties of a cloned 5hydroxytryptamine ionotropic receptor subunit: comparison with native mouse receptors. J Physiol 481:311-323.

Jansen M, Bali M, and Akabas MH (2008) Modular design of Cys-loop ligand-gated ion channels: functional 5-HT3 and GABA rho1 receptors lacking the large cytoplasmic M3M4 loop. J Gen Physiol 131:137-146.

Ji D and Dani JA (2000) Inhibition and disinhibition of pyramidal neurons by activation of nicotinic receptors on hippocampal interneurons. $J$ Neurophysiol 83: $2682-2690$

Jones DN, Barnes NM, Costall B, Domeney AM, Kilpatrick GJ, Naylor RJ, and Tyers MB (1992) The distribution of 5-HT3 recognition sites in the marmoset brain. Eur J Pharmacol 215:63-67.

Kelley SP, Bratt AM, and Hodge CW (2003a) Targeted gene deletion of the 5-HT3A receptor subunit produces an anxiolytic phenotype in mice. Eur $J$ Pharmacol 461: $19-25$

Kelley SP, Dunlop JI, Kirkness EF, Lambert JJ, and Peters JA (2003b) A cytoplasmic region determines single-channel conductance in 5-HT3 receptors. Nature 424: $321-324$.

Lemoine D, Jiang R, Taly A, Chataigneau T, Specht A, and Grutter T (2012) Ligandgated ion channels: new insights into neurological disorders and ligand recognition. Chem Rev 112:6285-6318.

Lochner M and Lummis SC (2010) Agonists and antagonists bind to an A-A interface in the heteromeric 5-HT3AB receptor. Biophys $J$ 98:1494-1502.

Lummis SC (2012) 5-HT(3) receptors. J Biol Chem 287:40239-40245. 
Maricq AV, Peterson AS, Brake AJ, Myers RM, and Julius D (1991) Primary structure and functional expression of the 5HT3 receptor, a serotonin-gated ion channel. Science 254:432-437.

Miquel MC, Emerit MB, Nosjean A, Simon A, Rumajogee P, Brisorgueil MJ, Doucet E, Hamon M, and Vergé D (2002) Differential subcellular localization of the 5-HT3As receptor subunit in the rat central nervous system. Eur J Neurosci 15:449-457.

Miyake A, Mochizuki S, Takemoto Y, and Akuzawa S (1995) Molecular cloning of human 5-hydroxytryptamine3 receptor: heterogeneity in distribution and function among species. Mol Pharmacol 48:407-416.

Morales M, Battenberg E, de Lecea L, and Bloom FE (1996) The type 3 serotonin receptor is expressed in a subpopulation of GABAergic neurons in the rat neocortex and hippocampus. Brain Res 731:199-202.

Nayak SV, Rondé P, Spier AD, Lummis SC, and Nichols RA (2000) Nicotinic receptors co-localize with 5 -HT(3) serotonin receptors on striatal nerve terminals. Neuropharmacology 39:2681-2690.

Niesler B, Frank B, Kapeller J, and Rappold GA (2003) Cloning, physical mapping and expression analysis of the human 5-HT3 serotonin receptor-like genes HTR3C, HTR3D and HTR3E. Gene 310:101-111.

Pandhare A, Hamouda AK, Staggs B, Aggarwal S, Duddempudi PK, Lever JR, Lapinsky DJ, Jansen M, Cohen JB, and Blanton MP (2012) Bupropion binds to two sites in the Torpedo nicotinic acetylcholine receptor transmembrane domain a photoaffinity labeling study with the bupropion analogue [(125)I]-SADU-3-72. Biochemistry 51:2425-2435.

Pandhare A, Pappu AS, Wilms H, Blanton MP, and Jansen M (2017) The antidepressant bupropion is a negative allosteric modulator of serotonin type $3 \mathrm{~A}$ receptors. Neuropharmacology 113 (Pt A):89-99.

Rajkumar R and Mahesh R (2010) The auspicious role of the 5-HT3 receptor in depression: a probable neuronal target? J Psychopharmacol 24:455-469.

Rammes G, Eisensamer B, Ferrari U, Shapa M, Gimpl G, Gilling K, Parsons C, Riering K, Hapfelmeier G, Bondy B, et al. (2004) Antipsychotic drugs antagonize human serotonin type 3 receptor currents in a noncompetitive manner. Mol Psychiatry 9:846-858, 818
Reeves DC, Goren EN, Akabas MH, and Lummis SC (2001) Structural and electrostatic properties of the 5-HT3 receptor pore revealed by substituted cysteine accessibility mutagenesis. J Biol Chem 276:42035-42042.

Schroeder DH (1983) Metabolism and kinetics of bupropion. J Clin Psychiatry 44: 79-81.

Slemmer JE, Martin BR, and Damaj MI (2000) Bupropion is a nicotinic antagonist. $J$ Pharmacol Exp Ther 295:321-327.

Stahl SM, Pradko JF, Haight BR, Modell JG, Rockett CB, and Learned-Coughlin S (2004) A review of the neuropharmacology of bupropion, a dual norepinephrine and dopamine reuptake inhibitor. Prim Care Companion J Clin Psychiatry 6:159-166.

Thompson AJ, Duke RK, and Lummis SC (2011) Binding sites for bilobalide, diltiazem, ginkgolide, and picrotoxinin at the 5-HT3 receptor. Mol Pharmacol 80:183-190.

Thompson AJ and Lummis SC (2007) The 5-HT3 receptor as a therapeutic target. Expert Opin Ther Targets 11:527-540.

Thompson AJ and Lummis SC (2013) Discriminating between 5- $\mathrm{HT}_{3} \mathrm{~A}$ and $5-\mathrm{HT}_{3} \mathrm{AB}$ receptors. Br J Pharmacol 169:736-747.

Tzvetkov MV, Meineke C, Oetjen E, Hirsch-Ernst K, and Brockmöller J (2007) Tissue-specific alternative promoters of the serotonin receptor gene HTR3B in human brain and intestine. Gene 386:52-62.

Vázquez-Gómez E, Arias HR, Feuerbach D, Miranda-Morales M, Mihailescu S, Targowska-Duda KM, Jozwiak K, and García-Colunga J (2014) Bupropion-induced inhibition of $\alpha 7$ nicotinic acetylcholine receptors expressed in heterologous cells and neurons from dorsal raphe nucleus and hippocampus. Eur J Pharmacol 740:103-111.

Walstab J, Rappold G, and Niesler B (2010) 5-HT(3) receptors: role in disease and target of drugs. Pharmacol Ther 128:146-169.

Address correspondence to: Dr. Michaela Jansen, Department of Cell Physiology and Molecular Biophysics, Center for Membrane Protein Research, School of Medicine, Texas Tech University Health Sciences Center, 3601 4th St., Lubbock, TX 79430. E-mail: michaela.jansen@ttuhsc.edu 